\title{
Pengembangan Model Bangkitan Perjalanan Zona Perumahan Dengan Mempertimbangkan Tipe Dan Usia Perumahan (Studi Kasus Perumahan di Kota Padang)
}

\author{
Development of a Model for Resurrection of Housing Zones \\ Considering Housing Type and Age \\ (Housing Case Study in Padang City)
}

\author{
${ }^{1}$ Rini Amelia Sari, ${ }^{2}$ Yosritzal, ${ }^{3}$ Purnawan \\ ${ }^{1}$ Mahasiswa Program Magister Teknik Sipil Universitas Andalas, riniameliasari01@gmail.com \\ ${ }^{2}$ Staf Pengajar Jurusan Teknik Sipil Universitas Andalas, yosritzal@ft.unand.ac.id \\ ${ }^{3}$ Staf Pengajar Jurusan Teknik Sipil Universitas Andalas, purnawan@ft.unand.ac.id
}

\begin{abstract}
Abstrak
Penelitian ini bertujuan memodelkan bangkitan pergerakan yang dilakukan oleh perumahan-perumahan yang ada di Kota Padang. Dengan mempertimbangkan variabel Tipe dan Umur Perumahan sebagai variabel tambahan di dalam model selain variabel sosio ekonomi, dengan tujuan menyederhanakan model dan memudahkan untuk memprediksi bangkitan perjalanan dari perumahan. Dalam penelitian ini ditemukan bahwa umur perumahan berkorelasi sangat rendah dengan bangkitan perjalanan perumahan. Yang berarti variabel umur perumahan tidak memberi pengaruh yang signifikan terhadap bangkitan perjalanan dari perumahan. Sedangkan variabel tipe rumah memberikan korelasi yang cukup tinggi dengan bangkitan perjalanan dengan mobil dengan $\mathrm{R}^{2}$ sebesar 0,583 , hal yang berbeda terjadi pada korelasi tipe rumah dengan bangkitan perjalanan dengan sepeda motor yaitu dengan $\mathrm{R}^{2}$ sangat rendah yaitu 0,09 . Variabel yang berkorelasi tinggi dalam bangkitan perjalanan adalah kepemilikan kendaraan, jumlah anggota keluarga dan anggaran yang mereka sediakan untuk transportasi. Pemodelan bangkitan oleh sepeda motor tidak di pengaruhi oleh tingkat ekonomi masyarakat, sedangkan bangkitan perjalanan oleh mobil berkorelasi positif dengan penghasilan masyarakat. Dari penelitian ini di hasilkan 12 model bangkitan perjalanan dari perumahan yang di dapatkan dari data total sampel dan dari sampel yang di bagi berdasarkan tipe rumah (Tipe Rumah 45, 70 dan 100). Nilai determinasi dari pemodelan ini umumnya berkisar pada angka 0,5. Yang berarti bahwa ada faktor lain yang mempengaruhi bangkitan perjalanan dari perumahan diluar dari variabel yang di teliti.
\end{abstract}

Kata kunci : korelasi, model, koefisien determinasi, variabel bebas, bangkitan perjalanan

\begin{abstract}
This study focus to model the trip generation conducted by existing housing in Padang City. Taking into account the Housing Type and Age variable as an additional variable in the model other than the socioeconomic variable, with the aim of simplifying the model and making it easier to predict the rise of the trip from the housing. In this study found that the age of housing correlates very low with the rise of residential travel. Which means the variable age of housing does not give a significant effect on the rise of travel from housing. While the type of house type gives a fairly high correlation with the trip generate by car with $R^{2}$ of 0.583 , different things happen in the correlation type of home with the trip generate by motorcycle with a very low $R^{2}$ of 0.09. Variables that are highly correlated in trip generation are vehicle ownership, number of family members and the budget they provide for transportation. Modeling the trip generate by motorcycles is not influenced by the economic level of society, while the trip generate by car is positively correlated with the income of the community. From this research, 12 models of trip generation from the housing obtained from the total sample data and from the sample are divided by type of house (Type of House 45, 70 and 100). The determination value of this modeling generally ranges from 0.5. Which means that there are other factors that influence the rise of travel from the housing outside of the variables in the perusal.
\end{abstract}

Keywords: correlation, model, coefficient of determination, independent variable, trip generation

PENDAHULUAN
Penelitian terdahulu telah banyak

yang membahas mengenai pemodelan 
bangkitan dari perumahan. Umumnya hanya menggunakan variabel sosio ekonomi sebagai variabel yang berpengaruh dalam pemodelan bangkitan perjalanan dari perumahan. Dalam penelitian ini akan dilihat pengaruh dari usia perumahan dan type perumahan apakah memberikan pengaruh pada bangkitkan perjalanan. Karena seiring dengan bertambahnya usia perumahan juga memberi pengaruh pada bangkitan perjalanan. Misalkan perumahan baru hanya di isi awalnya oleh sepasang suami istri. Dengan meningkatnya usia perumahan, keluarga juga tumbuh, punya anak dan anakpun mulai besar dan sekolah. Kondisi ini yang membangkitkan pola perjalanan yang panjang (berantai) karena orang tua harus mengantar anak sekolah terlebih dahulu sebelum berangkat ke kantor.

Karena itu ada peluang dilakukan pengembangan model bangkitan dengan menggabungkan variabel sosio ekonomi dengan type dan usia perumahan agar model yang didapatkan lebih mendekati kondisi yang sebenarnya.

\section{Tujuan Penelitian}

Tujuan penelitian ini adalah untuk menyusun model bangkitan perjalanan dari zona perumahan dengan mempertimbangkan faktor tipe dan umur perumahan sebagai variabel tambahan di luar variabel sosio ekonomi.

\section{Manfaat Penelitian}

Penelitian ini mengembangkan model baru dalam penilaian bangkitan perjalanan yang lebih reliable untuk memprediksi dampak lalu lintas suatu zona perumahan di masa mendatang.

\section{Batasan Masalah}

Untuk menghindari penelitian terlalu luas dan terbatasnya waktu, maka pembatasan masalah dalam penelitian akan menitik beratkan pada beberapa hal yaitu:

1. Perjalanan yang dilakukan oleh penghuni perumahan yang hanya dianalisis berdasarkan home base trip , yaitu semua perjalanan yang berasal dari rumah dan diakhiri dengan pulang kerumah.

2. Studi di lakukan terhadap beberapa Perumahan yang tersebar di Kota Padang.

3. Parameter yang dipakai dalam pembuatan model bangkitan pergerakan adalah metode analisis regresi linear berganda (Multiple Linear Regression Analysis), dan data diambil berdasarkan kecenderungan penghuni perumahan untuk melakukan perjalanan yang terjabarkan dalam beberapa variable, seperti: jumlah anggota keluarga, jumlah penghasilan keluarga, 
kepemilikan kendaraan, jenis pekerjaan, umur kepala keluarga, pendidikan kepala keluarga, tipe rumah, umur perumahan, lama tinggal di perumahan , perjalanan rutin anggota keluarga setiap pagi dan sore, dan berapa anggaran yang disediakan untuk transportasi dalam sebulan.

\section{METODOLOGI}

\section{Sampel Penelitian}

Mengingat bahwa populasi rumah berdasarkan tipe rumah dan berdasarkan umur rumah (usia rumah sejak di bangun pertama kali) tidak diketahui jumlahnya, maka untuk penelitian ini lebih tepat menggunakan metode Non Probabilty Sampling.

Dalam penelitian ini digunakan teknik Sampling Accidental yaitu teknik penentuan sample yang berdasarkan kebetulan, maksud dalam sampling ini yaitu siapa saja yang secara kebetulan/insidental bertemu dengan peneliti dapat digunakan sebagai sample penelitian (Sugiyono,2011).

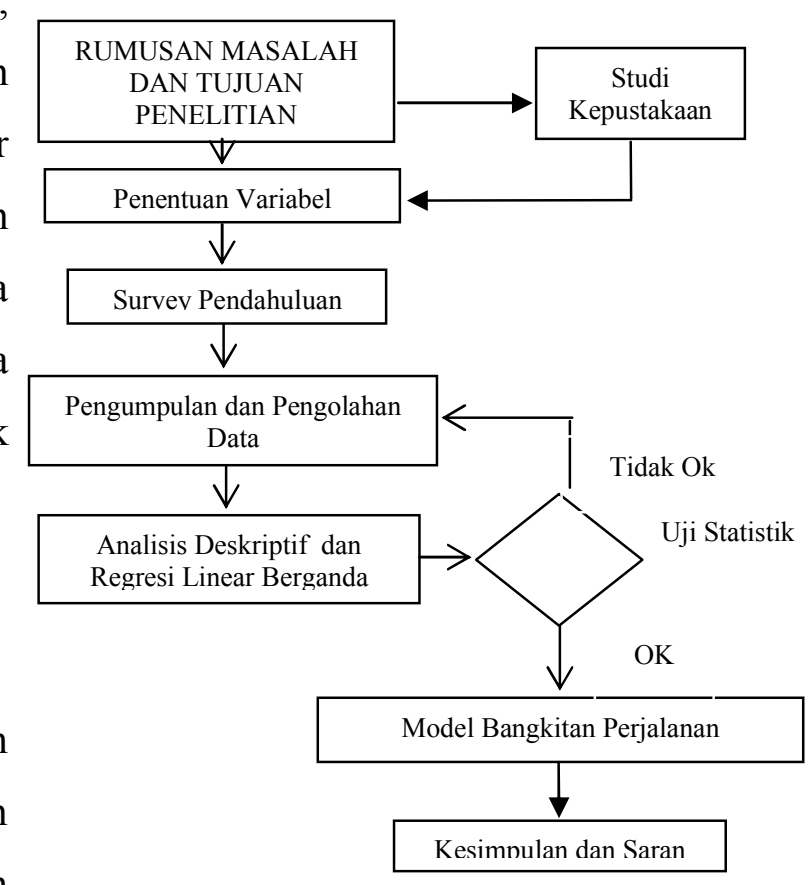

Gambar 2.1. Diagram Alir Penelitian

\section{Metode Analisis Data Penelitian}

Metode analisis data yang digunakan dalam studi ini adalah cara analisis regresi linier berganda dengan menggunakan perangkat lunak SPSS (Statistical Program for Social Science) yang merupakan paket program aplikasi komputer untuk menganalisa data terutama untuk ilmu-ilmu sosial.

Metoda ini adalah memasukkan semua variabel yang berkorelasi tinggi dengan variabel terikat, yang kemudian di evaluasi. Jika ada variabel yang tidak siginifikan maka variabel tersebut akan dikeluarkan dan dilakukan lagi proses evaluasi sampai semua variabelnya memenuhi syarat siginifikansi.

Dalam menganalisis dengan SPSS, beberapa tahapan yang harus dilakukan 
agar model bangkitan perjalanan yang dihasilkan menjadi model yang valid. Tahapan-tahapan itu adalah :

a. Analisis Bivariat

Analisis Bivariat dilakukan dengan Uji korelasi Pearson untuk mengetahui kekuatan/keeratan hubungan antar variabel yaitu variabel bebas dengan variabel tak bebas maupun antar variabel bebas. Hasil dari uji korelasi dinyatakan dengan koefisien korelasi, dimana dengan nilai koefisien korelasi ini dapat diketahui tingkat keterhubungan antara variabel tak bebas dan variabel bebas yang mana sangat berguna dalam menganalisis tingkat keterhubungan tersebut.

Untuk hubungan antar variabel bebas akan dipilih variabel bebas yang memiliki nilai korelasi tidak kuat atau $<0,6$, sedangkan hubungan antara variabel bebas dan variabel tak bebas akan dipilih variabel bebas yang memiliki korelasi yang tinggi diantara yang ada (minimal $\geq 0,2)$, biasanya ditandai dengan tanda bintang pada hasil SPSS.

b. Analisis Regresi Linear Berganda Analisis regresi linear berganda digunakan untuk meramalkan suatu variabel terikat $\mathrm{Y}$ berdasarkan dua atau lebih variabel bebas dalam suatu persamaan linear. Model regresi linear berganda yang diolah dengan bantuan software SPSS-20.

c. Uji Asumsi Klasik

- Uji Multikolinearitas

- Uji Heteroskedastisitas

- Uji Normalitas

d. Uji Signifikansi Model/Uji Statistik

- Uji t

- Uji F

- Koefisien determinasi $\left(\mathrm{R}^{2}\right)$

e. Validasi Model

Validasi model umumnya dilakukan dengan menggunakan metode perbandingan secara statistik. Salah satu metode statistik yang dapat digunakan untuk memvalidasi model adalah Metode Chi-Square. Metode ini mampu memberikan batasan yang jelas apakah performa model yang kita gunakan valid atau tidak.

\section{HASIL DAN PEMBAHASAN}

\section{Lokasi Penelitian}

Lokasi penelitian di lakukan pada perumahan-perumahan yang tersebar di Kota Padang. Data penelitian ini berasal dari data primer dan data sekunder. Data primer di dapat dari hasil survei rumah tangga.

Surveyor menyebar 800 kuisioner, jumlah kuisioner yang kembali dan data nya lengkap 770. Dari yang 770 kuisioner ini, 680 data digunakan untuk analisis pemodelan, sementara sisanya di gunakan 
untuk validasi data dengan metoda chisquare.

\section{Karakteristik Perumahan}

Dari 680 Rumah yang di survei berdasarkan luas rumah terdapat Tipe 36 (41.91\%), Tipe 45 (24.12\%) dan Tipe 70 (18.24\%). Seiring waktu karena faktor kebutuhan dan di dukung oleh dukungan financial dari penghuni rumah, rumahrumah tersebut umumnya mengalami perubahan luas. Pada Gambar 3.1 terdapat data mengenai tipe rumah yang sekarang, yang telah berubah dari tipe semula.

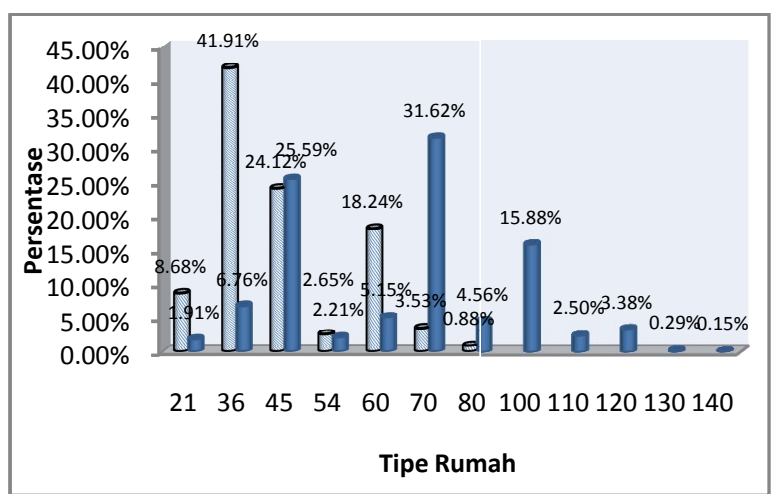

Gambar 3.1 Grafik Perubahan Rumah Tipe awal ke Tipe Sekarang

Tabel 3.1 Data Tipe Rumah Sekarang dan Umur Perumahan

\begin{tabular}{|l|r|r|r|r|r|}
\hline \multirow{2}{*}{\begin{tabular}{c} 
Tipe $\begin{array}{c}\text { Perumahan } \\
\text { Se karang (m2) }\end{array}$ \\
\cline { 2 - 6 }
\end{tabular}} & \multicolumn{3}{c|}{ Umur Perumahan } & \multicolumn{1}{c|}{ Total } \\
\cline { 2 - 6 } & tahun & tahun & tahun & tahun & \\
\hline 21 & & & 1 & 12 & 13 \\
\hline 36 & & & 6 & 40 & 46 \\
\hline 45 & 1 & 5 & 29 & 139 & 174 \\
\hline 54 & & & 2 & 13 & 15 \\
\hline 60 & & & 5 & 30 & 35 \\
\hline 70 & 4 & 15 & 35 & 161 & 215 \\
\hline 80 & & & & 31 & 31 \\
\hline 100 & 17 & & 5 & 86 & 108 \\
\hline 110 & & & & 17 & 17 \\
\hline 120 & 2 & & 2 & 19 & 23 \\
\hline 130 & & & & 1 & 2 \\
\hline 140 & $\mathbf{2 4}$ & $\mathbf{2 0}$ & $\mathbf{8 5}$ & $\mathbf{5 5 1}$ & $\mathbf{6 8 0}$ \\
\hline Grand Total & & & & & 1 \\
\hline
\end{tabular}

Sumber : Pengolahan Data

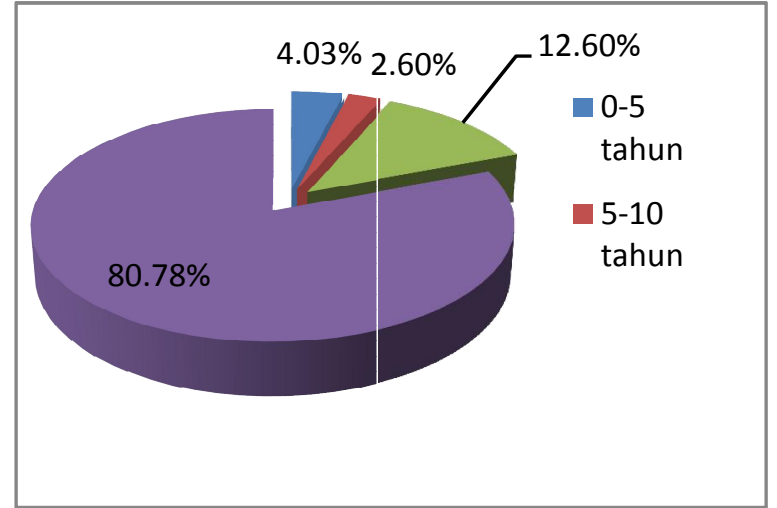

Gambar 3.2 Data Perumahan Berdasarkan Umur Perumahan

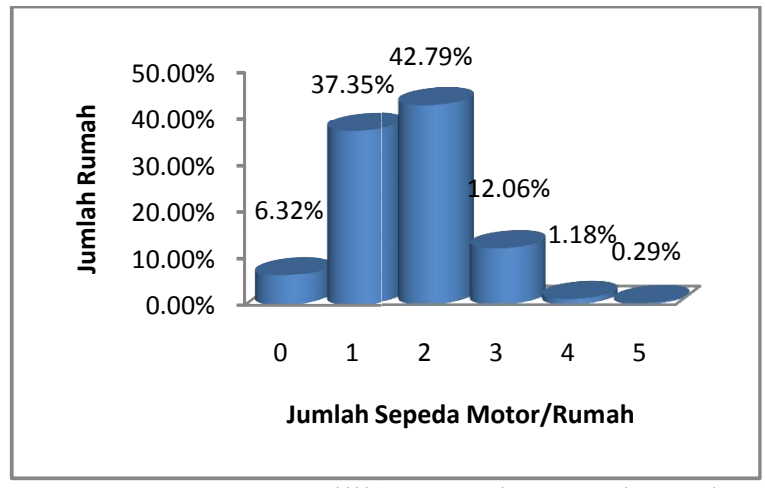

Gambar 3.3 Kepemilikan Sepeda Motor/Rumah

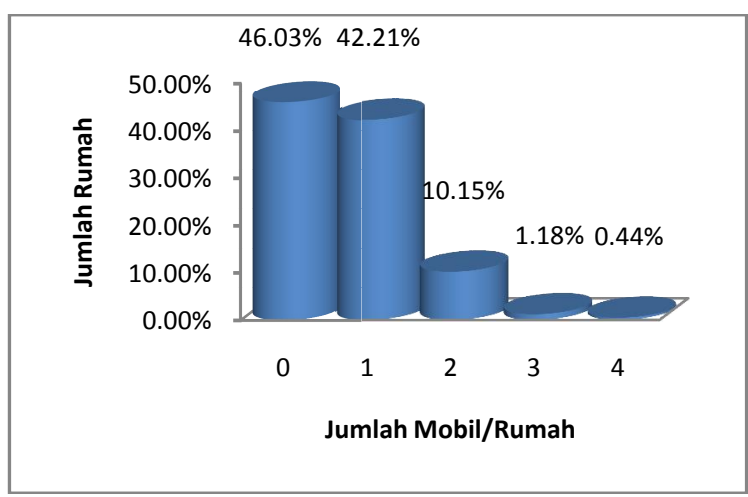

Gambar 3.4 Jumlah Kepemilikan Mobil/Rumah 
Kepemilikan Kendaraan Bermotor dan Tipe Rumah

Tabel 3.2 Data Kepemilikan Sepeda Motor dan Tipe Rumah

\begin{tabular}{|c|c|c|c|c|c|c|c|}
\hline \multirow{2}{*}{ Tipe Rumah } & \multicolumn{6}{|c|}{\begin{tabular}{c|} 
Jumlah Sepeda Motor \\
Dalam Satu Rumah \\
\end{tabular}} & \multirow[t]{2}{*}{ Grand Total } \\
\hline & $\mathbf{0}$ & 1 & 2 & 3 & 4 & 5 & \\
\hline 21 & & 4 & 6 & 3 & & & 13 \\
\hline 36 & 5 & 16 & 18 & 7 & & & 46 \\
\hline 45 & 9 & 81 & 63 & 17 & 3 & 1 & 174 \\
\hline 54 & 1 & 8 & 2 & 4 & & & 15 \\
\hline 60 & 6 & 10 & 15 & 3 & 1 & & 35 \\
\hline 70 & 8 & 76 & 110 & 18 & 2 & 1 & 215 \\
\hline 80 & & 14 & 13 & 4 & & & 31 \\
\hline 100 & 12 & 32 & 46 & 16 & 2 & & 108 \\
\hline 110 & & 4 & 9 & 4 & & & 17 \\
\hline 120 & 2 & 7 & 9 & 5 & & & 23 \\
\hline 130 & & 2 & & & & & 2 \\
\hline 140 & & & & 1 & & & 1 \\
\hline Grand Total & 43 & 254 & 291 & 82 & 8 & 2 & 680 \\
\hline
\end{tabular}

Sumber : Pengolahan Data

Tabel 3.3 Data Kepemilikan Mobil dan Tipe Rumah

\begin{tabular}{|l|r|r|r|r|r|r|}
\hline \multirow{2}{*}{ Tipe Rumah } & \multicolumn{4}{|c|}{$\begin{array}{c}\text { Jumlah Mobil Dalam } \\
\text { Satu Rumah }\end{array}$} \\
\cline { 2 - 5 } & $\mathbf{0}$ & $\mathbf{1}$ & $\mathbf{2}$ & $\mathbf{3}$ & $\mathbf{4}$ & \multicolumn{1}{c}{ Total } \\
\hline 21 & 12 & 1 & & & & 13 \\
\hline 36 & 21 & 16 & 9 & & & 46 \\
\hline 45 & 87 & 75 & 12 & & & 174 \\
\hline 54 & 10 & 4 & 1 & & & 15 \\
\hline 60 & 15 & 13 & 6 & 1 & & 35 \\
\hline 70 & 106 & 87 & 16 & 3 & 3 & 215 \\
\hline 80 & 8 & 19 & 4 & & & 31 \\
\hline 100 & 40 & 52 & 14 & 2 & & 108 \\
\hline 110 & 4 & 9 & 3 & 1 & & 17 \\
\hline 120 & 9 & 11 & 3 & & & 23 \\
\hline 130 & 1 & & & 1 & & 2 \\
\hline 140 & & & 1 & & & 1 \\
\hline Grand Total & $\mathbf{3 1 3}$ & $\mathbf{2 8 7}$ & $\mathbf{6 9}$ & $\mathbf{8}$ & $\mathbf{3}$ & $\mathbf{6 8 0}$ \\
\hline
\end{tabular}

Sumber : Pengolahan Data

\section{Analisis Pengaruh Karakteristik \\ Rumah Tangga Terhadap Jumlah Perjalanan Identifikasi Perjalanan \\ Keluar Perumahan}

Dalam survei rumah tangga ini, data pergerakan yang di ambil adalah data total pergerakan/perjalanan penghuni rumah keluar perumahan dalam satu minggu, baik itu menggunakan sepeda motor ataupun mobil.

Dari total sampel 680 rumah tangga terlihat pada Tabel 4.1 sampai dengan Tabel 4.5 rata-rata perjalanan yang di lakukan oleh penghuni rumah dengan menggunakan motor, mobil dan gabungan perjalanan motor dan mobil dalam satu minggu.

Tabel 4.1 Rata-rata Perjalanan Rumah Tangga Dalam 1 minggu

\begin{tabular}{|l|c|c|}
\hline \multicolumn{1}{|c|}{ Jenis Perjalanan } & $\begin{array}{c}\text { Rata-rata } \\
\text { Perjalanan dalam 1 } \\
\text { Minggu }\end{array}$ & $\begin{array}{c}\text { Rata-rata } \\
\text { Perjalanan } \\
\text { dalam 1 hari }\end{array}$ \\
\hline $\begin{array}{l}\text { Perjalanan Total Keluarga } \\
\text { dengan mobil }\end{array}$ & 4.47 & 0.64 \\
\hline $\begin{array}{l}\text { Perjalanan Total Keluarga } \\
\text { dengan sepeda motor }\end{array}$ & 14.36 & 2.05 \\
\hline $\begin{array}{l}\text { Perjalanan Total Keluarga } \\
\text { dengan mobil dan sepeda } \\
\text { motor }\end{array}$ & 18.83 & 2.69 \\
\hline
\end{tabular}

Sumber : Pengolahan Data

Tabel 4.2 Jumlah Perjalanan Rumah Tangga Dalam 1 Minggu berdasarkan Jumlah Anggota Keluarga

\begin{tabular}{|c|c|c|c|c|}
\hline $\begin{array}{c}\text { Jumlah } \\
\text { Keluarga }\end{array}$ & $\begin{array}{c}\text { Perjalanan } \\
\text { Total } \\
\text { Keluarga } \\
\text { dengan } \\
\text { mobil }\end{array}$ & $\begin{array}{c}\text { Perjalanan } \\
\text { Total } \\
\text { Keluarga } \\
\text { dengan } \\
\text { sepeda } \\
\text { motor }\end{array}$ & $\begin{array}{c}\text { Perjalanan } \\
\text { Total } \\
\text { Keluarga } \\
\text { dengan } \\
\text { mobil dan } \\
\text { sepeda } \\
\text { motor }\end{array}$ & $\begin{array}{c}\text { Jumlah } \\
\text { Rumah } \\
\text { Tangga }\end{array}$ \\
\hline 1 & 0.88 & 6.63 & 7.5 & 16 \\
\hline 2 & 3.68 & 8.44 & 12.12 & 41 \\
\hline 3 & 3.94 & 10.93 & 14.86 & 111 \\
\hline 4 & 4.69 & 13.96 & 18.65 & 222 \\
\hline 5 & 5.09 & 15.96 & 21.05 & 185 \\
\hline 6 & 5.21 & 17.62 & 22.82 & 68 \\
\hline 7 & 2.42 & 21.54 & 23.96 & 24 \\
\hline 8 & 7 & 24.25 & 31.25 & 4 \\
\hline 9 & 0.75 & 25.5 & 26.25 & 4 \\
\hline 10 & 4 & 35 & 39 & 1 \\
\hline 11 & 1.67 & 16.67 & 18.33 & 3 \\
\hline 13 & 1 & 50 & 51 & 1 \\
\hline Rata-Rata & $\mathbf{4 . 4 7}$ & $\mathbf{1 4 . 3 6}$ & $\mathbf{1 8 . 8 3}$ & $\mathbf{6 8 0}$ \\
\hline
\end{tabular}

Sumber : Pengolahan Data 
Tabel 4.3 Jumlah Perjalanan Rumah Tangga Dalam 1 Minggu berdasarkan Jumlah Kepemilikan Sepeda Motor

\begin{tabular}{|c|c|c|c|c|c|c}
\hline \multirow{2}{*}{ Jenis Perjalanan } & \multicolumn{6}{|c|}{ Kepemilikan Sepeda Motor/Rumah } \\
\cline { 2 - 7 } & $\mathbf{0}$ & $\mathbf{1}$ & $\mathbf{2}$ & $\mathbf{3}$ & $\mathbf{4}$ & $\mathbf{5}$ \\
\hline $\begin{array}{c}\text { Rata-rata Perjalananan } \\
\text { Total Keluarga dengan } \\
\text { sepeda motor }\end{array}$ & - & 11.48 & 16.26 & 22.4 & 25.25 & 40 \\
\hline
\end{tabular}

Sumber : Pengolahan Data

Tabel 4.4 Jumlah Perjalanan Rumah Tangga Dengan Mobil Dalam 1 Minggu berdasarkan Jumlah Kepemilikan Mobil

\begin{tabular}{|c|c|c|c|c|c|}
\hline \multirow{2}{*}{ Jenis Perjalanan } & \multicolumn{5}{|c|}{ Kepemilikan Mobil/Rumah } \\
\cline { 2 - 6 } & $\mathbf{0}$ & $\mathbf{1}$ & $\mathbf{2}$ & $\mathbf{3}$ & $\mathbf{4}$ \\
\hline $\begin{array}{c}\text { Perjalanan Total } \\
\text { Keluarga dengan } \\
\text { mobil }\end{array}$ & & 7.19 & 12.8 & 9.5 & 5.33 \\
\hline
\end{tabular}

Sumber : Pengolahan Data

Tabel 4.5. Jumlah Perjalanan Rumah Tangga Dengan Mobil Dalam 1 Minggu berdasarkan Jumlah Kepemilikan Mobil dan Sepeda Motor

\begin{tabular}{|c|c|c|c|c|c|c|c}
\hline \multirow{2}{*}{ Jenis Perjalanan } & \multicolumn{6}{|c|}{ Kepemilikan Mobil dan Sepeda Motor/Rumah } \\
\cline { 2 - 8 } & 0 & 1 & 2 & 3 & 4 & 5 & 6 \\
\hline $\begin{array}{c}\text { Perjalanan Total } \\
\begin{array}{c}\text { Keluarga dengan } \\
\text { mobil dan sepeda } \\
\text { motor }\end{array}\end{array}$ & - & 11.15 & 17.72 & 22.18 & 27.98 & 33 & 33 \\
\hline
\end{tabular}

Sumber : Pengolahan Data

\section{Jumlah Perjalanan Rumah Tangga}

\section{Dalam 1 Minggu dan Karakteristik}

\section{Perumahan}

Berikut ini peneliti mencoba memasukan data karakteristik perumahan dalam analisis bangkitan perjalanan dari perumahan. Tabel 4.6 memperlihatkan bahwa jumlah perjalanan yang dilakukan oleh rumah tangga tidak ada memperlihatkan korelasi yang kuat baik positif ataupun negatif dengan umur perumahan.
Tabel 4.6 Jumlah Perjalanan Rumah Tangga Dalam 1 Minggu dan Umur Perumahan

\begin{tabular}{|l|c|c|c|c|}
\hline \multicolumn{1}{|c|}{ Jenis Perjalanan } & $\begin{array}{c}\mathbf{0 - 5} \\
\text { tahun }\end{array}$ & $\begin{array}{c}\mathbf{5 - 1 0} \\
\text { tahun }\end{array}$ & $\begin{array}{c}\mathbf{1 0 - 1 5} \\
\text { tahun }\end{array}$ & $\begin{array}{c}\mathbf{1 5 - 2 0} \\
\text { tahun }\end{array}$ \\
\hline $\begin{array}{l}\text { Perjalanan Total } \\
\text { Keluarga dengan mobil }\end{array}$ & 10.96 & 5.45 & 3.84 & 4.25 \\
\hline $\begin{array}{l}\text { Perjalanan Total } \\
\text { Keluarga dengan } \\
\text { sepeda motor }\end{array}$ & 12.83 & 20.05 & 11.74 & 14.63 \\
\hline $\begin{array}{l}\text { Perjalanan Total } \\
\text { Keluarga dengan mobil } \\
\text { dan sepeda motor }\end{array}$ & 23.79 & 25.5 & 15.58 & 18.87 \\
\hline
\end{tabular}

Sumber : Pengolahan Data

Tabel 4.7 mempelihatkan perjalanan yang dilakukan oleh penghuni rumah berdasarkan type rumah yang dimiliki.

\section{Pemodelan Bangkitan Perjalanan}

Variabel-variabel yang di gunakan untuk mendapatkan pemodelan bangkitan perjalanan terlihat pada Tabel 4.8. Variabel Terikat adalah Y dan variabel bebasnya adalah $\mathrm{x}$.

Tabel 4.7 Jumlah Perjalanan Rumah Tangga Dalam 1 Minggu dan Tipe Perumahan

\begin{tabular}{|c|c|c|c|c|}
\hline $\begin{array}{c}\text { Tipe } \\
\text { Rumah }\end{array}$ & $\begin{array}{c}\text { Jumlah } \\
\text { Rumah }\end{array}$ & $\begin{array}{c}\text { Perjalanan } \\
\text { Total } \\
\text { Keluarga } \\
\text { dengan } \\
\text { mobil }\end{array}$ & $\begin{array}{c}\text { Perjalanan } \\
\text { Total } \\
\text { Keluarga } \\
\text { dengan } \\
\text { sepeda } \\
\text { motor }\end{array}$ & $\begin{array}{c}\text { Perjalanan } \\
\text { Total } \\
\text { Keluarga } \\
\text { dengan } \\
\text { mobil dan } \\
\text { sepeda } \\
\text { motor }\end{array}$ \\
\hline 21 & 13 & 0.31 & 22.38 & 22.69 \\
\hline 36 & 46 & 6.76 & 15.78 & 22.54 \\
\hline 45 & 174 & 3.75 & 12.92 & 16.67 \\
\hline 54 & 15 & 2.73 & 13.6 & 16.33 \\
\hline 60 & 35 & 4.2 & 11.63 & 15.83 \\
\hline 70 & 215 & 3.8 & 15.37 & 19.16 \\
\hline 80 & 31 & 5.48 & 13.94 & 19.42 \\
\hline 100 & 108 & 5.58 & 13.66 & 19.24 \\
\hline 110 & 17 & 5.94 & 17.88 & 23.82 \\
\hline 120 & 23 & 7.04 & 14 & 21.04 \\
\hline 130 & 2 & 10 & 14 & 24 \\
\hline 140 & 1 & 10 & 25 & 35 \\
\hline Grand Tota & $\mathbf{6 8 0}$ & $\mathbf{4 . 4 7}$ & $\mathbf{1 4 . 3 6}$ & $\mathbf{1 8 . 8 3}$ \\
\hline Sum : Pengo & & & \\
\hline
\end{tabular}

Sumber : Pengolahan Data 
Tabel 4.8 Variabel-Variabel dalam Pemodelan Bangkitan

\begin{tabular}{|l|}
\hline Perjalanan Total Keluarga dengan Mobil \\
\hline Perjalanan Total keluarga dengan Sepeda Motor \\
\hline Perjalanan Totak keluarga dengan Mobil dan Sepeda Motor \\
\hline Penghasilan Total Keluarga \\
\hline Jumlah Anggota Keluarga \\
\hline Jumlah Kepemilikan Mobil \\
\hline Jumlah Kepemilikan Sepeda Motor \\
\hline Jumlah Kepemilikan Mobil dan Motor \\
\hline Anggaran Transportasi \\
\hline Lama Tinggal \\
\hline Umur Perumahan \\
\hline
\end{tabular}

Sumber : Pengolahan Data

\section{Pemodelan Bangkitan Pergerakan Oleh} Mobil

\section{a. Analisis Bivariate (Uji Korelasi Pearson)}

Sebagai tahapan awal dalam menilai kelayakan variabel untuk digunakan dalam pemodelan regresi linier berganda bangkitan pergerakan, maka terlebih dahulu dilakukan analisis korelasi antar variabel-variabel penelitian . Hasilhasil analisis korelasi antar variabel dengan menggunakan program aplikasi SPSS 20.0 disajikan pada Tabel 4.9

\section{Berdasarkan Tabel 4.9 dapat} dilihat bahwa nilai korelasi variabel $\mathrm{X}_{1}$ dan $\mathrm{Y}_{\mathrm{A} 1}$ cukup tinggi yaitu 0.536 . Korelasi $\mathrm{X}_{6}$ dengan $\mathrm{Y}_{\mathrm{A} 1}$ adalah 0,527 juga tinggi. Korelasi Variabel $\mathrm{X}_{3}$ dengan $\mathrm{Y}_{\mathrm{A} 1}$ adalah paling tinggi yaitu 0,753 yang sama artinya bahwa variabel bebas $\mathrm{X}_{3}$ dapat mempengaruhi variabel terikat $\mathrm{Y}_{\mathrm{A} 1}$ sebesar 75,3\%. Namun variabel $\mathrm{X}_{7}$ (Lama tinggal) dan $\mathrm{X}_{8}$ (Umur perumahan) dengan $\mathrm{Y}_{\mathrm{A} 1}$ berkorelasi sangat rendah yaitu $-0,004$ dan $-0,151$.

Tabel 4.9 Korelasi Antar Variabel $Y_{\mathrm{A1}}$ dengan Variable Bebas

\begin{tabular}{|c|c|c|c|c|c|c|c|}
\hline & YA 1 & $\mathrm{X} 1$ & $\mathrm{X} 2$ & $\mathrm{X} 3$ & X6 & X7 & $\mathrm{X} 8$ \\
\hline YA 1 & 1 & $.536^{* *}$ & 0.044 & $.753^{* *}$ & $.527^{* *}$ & -0.004 & $-.151^{* *}$ \\
\hline $\mathrm{X} 1$ & $.536^{* *}$ & 1 & $.180^{* *}$ & $.602^{* *}$ & $.350^{* *}$ & -0.043 & $-.255^{* *}$ \\
\hline $\mathrm{X} 2$ & 0.044 & $.180^{* * *}$ & 1 & $.149^{* *}$ & 0.069 & $.212^{* * *}$ & 0.045 \\
\hline X3 & $.753^{* *}$ & $.602^{* *}$ & $.149^{* *}$ & 1 & $.554^{* *}$ & $.087^{*}$ & -0.067 \\
\hline X6 & $.527^{* *}$ & $.350^{* *}$ & 0.069 & $.554^{* *}$ & 1 & 0.035 & $-.121^{* *}$ \\
\hline $\mathrm{X} 7$ & -0.004 & -0.043 & $.212^{* *}$ & $.087^{*}$ & 0.035 & 1 & $.375^{* *}$ \\
\hline $\mathrm{X} 8$ & $-.151^{* *}$ & $-.255^{* *}$ & 0.045 & -0.067 & $-.121^{* *}$ & $.375^{* * *}$ & 1 \\
\hline
\end{tabular}

Sumber : Analisis Data

Salah satu syarat untuk model analisis regresi berganda yang baik adalah antar variabel bebas tidak boleh saling berkolerasi. Apabila terdapat korelasi yang kuat $(r \geq 0,6)$ antar variabel bebas, maka dipilih salah satu yang mempunyai korelasi paling tinggi dengan variabel terikat untuk mewakili. Pada Tabel 4.9 terlihat bahwa antara variabel $X_{1}$ dan $X_{3}$ memiliki korelasi sebesar 0,602. Nilai sebesar 0.602 termasuk dalam kategori korelasi kuat. Sehingga diantara variabel $\mathrm{X}_{1}$ dan $\mathrm{X}_{3}$ yang paling kuat korelasinya dengan $Y_{A 1}$ adalah $X_{3}$ sehingga variabel $\mathrm{X}_{1}$ di keluarkan dari model.

Dari uraian di atas dapat disimpulkan bahwa hanya dua variabel bebas yang dapat di pakai dalam model, yaitu variabel Jumlah Kepemilikan Mobil $\left(\mathrm{X}_{3}\right)$, dan Anggaran Transportasi $\left(\mathrm{X}_{6}\right)$. 


\section{b. Analisis Regresi Linear Berganda}

Analisis regresi linear berganda digunakan untuk meramalkan suatu variabel terikat $\mathrm{Y}$ berdasarkan dua atau lebih variabel bebas dalam suatu persamaan linear. Untuk mendapatkan model yang paling sesuai menggambarkan pengaruh satu atau beberapa variabel bebas terhadap variabel terikatnya dapat digunakan analisis regresi linear berganda. Model regresi linear berganda diolah dengan bantuan software SPSS-20. Tahapan regresi linear berganda untuk mendapatkan model bangkitan perjalanan penghuni perumahan dengan menggunakan mobil akan dijelaskan berikut ini :

\section{Data Masukan}

Data input yang dimasukkan ke dalam SPSS untuk variabel bebas adalah Variabel bebas yang dimasukkan hanya variabel bebas yang sudah lolos seleksi uji korelasi Pearson yaitu data Jumlah Kepemilikan Mobil $\left(\mathrm{X}_{3}\right)$ dan Anggaran Transportasi $\left(\mathrm{X}_{6}\right)$.

Sedangkan data input yang dimasukkan ke dalam SPSS untuk variabel terikat adalah Perjalanan Total Keluarga dengan Mobil (YA1).
Tabel 4.10 Hasil Pengolahan Data (Output)Statistik deskriptif untuk Model-YA1

\begin{tabular}{|l|r|r|r|}
\hline & Mean & \multicolumn{1}{|c|}{$\begin{array}{c}\text { Std. } \\
\text { Deviation }\end{array}$} & $\mathrm{N}$ \\
\hline $\begin{array}{l}\text { Perjalanantotalkeluargade } \\
\text { nganmobildlmlminggu }\end{array}$ & 4.47 & 5.455 & 680 \\
$\begin{array}{l}\text { Mobil } \\
\begin{array}{l}\text { Anggaran transportasi } \\
\text { tiap bulan (Juta) }\end{array}\end{array}$ & 0.68 & 0.739 & 680 \\
\hline
\end{tabular}

Sumber : Analisis Data

Tabel 4.10 di atas merupakan hasil olah data dengan SPSS yang memperlihatkan statitistik deskriptif yaitu rata-rata variabel terikat dan variabel bebas (mean) dan standar deviasi masing-masing variabel dari jumlah sampel penelitian (N) sebanyak 680 buah. Terlihat bahwa ratarata perjalanan dengan mobil dalam satu minggu sebesar 4,47 dengan rata-rata kepemilikan mobil rata-rata 0,68 dan jumlah anggaran transportasi sebesar 0,57 juta per bulan.

Tabel 4.11 Model Summary ${ }^{\mathrm{c}}$ untuk Model- $\mathrm{Y}_{\mathrm{A} 1}$

\begin{tabular}{|c|c|c|c|c|}
\hline Model & $\mathrm{R}$ & R Square & $\begin{array}{c}\text { Adjusted } \\
\text { R Square }\end{array}$ & $\begin{array}{c}\text { Std. Error } \\
\text { of the } \\
\text { Estimate }\end{array}$ \\
\hline 1 & $.765^{\mathrm{a}}$ & 0.585 & 0.584 & 3.518 \\
\hline
\end{tabular}

a. Predictors: (Constant), Anggaran transportasi tiap bulan (Juta), Mobil

b. Dependent Variable:

Perjalanantotalkeluargadenganmobildlmlminggu

Sumber : Analisis Data

Koefisien determinasi menjelaskan variasi pengaruh variabel-variabel bebas terhadap variabel terikatnya. Atau dapat pula dikatakan sebagai proporsi pengaruh seluruh variabel bebas terhadap variabel 
terikat. Nilai koefisien determinasi dapat diukur oleh nilai $R$ square atau Adjusted $R$-Square. $R$-Square digunakan pada saat variabel bebas hanya 1 saja (biasa disebut dengan Regresi Linier Sederhana), sedangkan Adjusted R-Square digunakan pada saat variabel bebas lebih dari satu.

Dari hasil ouput model summary di atas terlihat bahwa nilai $\mathrm{R}$ (koefisien korelasi) pada Model- $Y_{\mathrm{A} 1}$ sebesar 0,765 yang berarti bahwa variabel bebas dan variabel terikat dapat dikategorikan memiliki hubungan linear yang cukup kuat.

Nilai Adjusted R-Square pada Model- $\mathrm{Y}_{\mathrm{A} 1}$ sebesar 0,584, hal ini menunjukkan bahwa Jumlah Kepemilikan Mobil dan anggaran transportasi dalam sebulan berpengaruh $58,40 \%$ terhadap jumlah bangkitan perjalanan dengan menggunakan mobil dalam seminggu dan $41,60 \%$ dipengaruhi oleh variabel lain yang tidak diteliti.

\section{Uji Statistik Regresi Linear Berganda}

Adapun uji statistik regresi linear berganda yang digunakan dalam penelitian ini adalah uji statistik $\mathrm{F} / \mathrm{uji}$ simultan/Anova dan uji statistik T/uji parsial.

\section{Uji Koefisien Regresi (Uji t)}

Uji t dalam regresi linier berganda dimaksudkan untuk menguji apakah parameter (koefisien regresi dan konstanta) yang diduga untuk mengestimasi persamaan/model regresi linier berganda sudah merupakan parameter yang tepat atau belum. Maksud tepat disini adalah parameter tersebut mampu menjelaskan perilaku variabel bebas dalam mempengaruhi variabel terikatnya. Parameter yang diestimasi dalam regresi linier meliputi intersep (konstanta) dan slope (koefisien dalam persamaan linier). Pada bagian ini, uji $\mathrm{t}$ difokuskan pada parameter slope (koefisien regresi) saja. Jadi uji t yang dimaksud adalah uji koefisien regresi.

Hasil pengujian dapat dilihat pada Tabel 4.12. Dengan SPSS uji t juga dapat dengan mudah ditarik kesimpulannya. Apabila nilai prob. $\mathrm{t}$ hitung (ouput SPSS ditunjukkan pada kolom sig.) lebih kecil dari tingkat kesalahan (alpha) 0,05 (yang telah ditentukan) maka dapat dikatakan bahwa variabel bebas (dari $\mathrm{t}$ hitung tersebut) berpengaruh signifikan terhadap variabel terikatnya, sedangkan apabila nilai prob. $\mathrm{t}$ hitung lebih besar dari tingkat kesalahan 0,05 maka dapat dikatakan bahwa variabel bebas tidak berpengaruh signifikan terhadap variabel terikatnya. 
Tabel 4.12 Tabel Coeffisients Output SPSS

\begin{tabular}{|c|c|c|c|c|c|c|c|}
\hline \multirow{2}{*}{ Model } & \multicolumn{2}{|c|}{$\begin{array}{c}\text { Unstandardized } \\
\text { Coefficients }\end{array}$} & $\begin{array}{c}\text { Standardiz } \\
\text { ed } \\
\text { Coefficient } \\
\mathrm{s}\end{array}$ & $\mathrm{t}$ & Sig. & \multicolumn{2}{|c|}{$\begin{array}{c}\text { Collinearity } \\
\text { Statis tics }\end{array}$} \\
\cline { 2 - 5 } & $\mathrm{B}$ & Std. Error & Beta & & & Tolerance & $\mathrm{VIF}$ \\
\hline (Constant) & 0.465 & 0.188 & & 2.472 & 0.014 & & \\
\hline $\begin{array}{c}\text { Mobil } \\
1\end{array}$ & 4.915 & 0.22 & 0.666 & 22.383 & 0 & 0.693 & 1.443 \\
\hline $\begin{array}{c}\text { Anggaran } \\
\text { transporta } \\
\text { si tiap } \\
\text { bulan } \\
\text { (Juta) }\end{array}$ & 1.172 & 0.22 & 0.159 & 5.337 & 0 & 0.693 & 1.443 \\
\hline
\end{tabular}

a. Dependent Variable: Perjalanantotalkeluargadenganmobildlmlminggu Sumber : Analisis Data

Hipotesis

$\mathrm{H}_{0}=$ (Secara parsial variabel bebas $\mathrm{Xi}$ tidak ada pengaruh signifikan terhadap variabel terikat $\left.\mathrm{Y}_{1 \mathrm{~A}}\right)$.

$\mathrm{H}_{1}=$ (Secara parsial variabel bebas $\mathrm{Xi}$ ada pengaruh signifikan terhadap variabel terikat $\left.\mathrm{Y}_{1 \mathrm{~A}}\right)$.

Tingkat signifikansi

$\alpha=0,05$ atau $5 \%$

Daerah kritis

$\mathrm{T}_{\text {hitung }}>\mathrm{T}_{\text {Tabel }} ;$ Tolak $\mathrm{H}_{0}$

Sig. $\leq \alpha ;$ Tolak $\mathrm{H}_{0}$

Uji-T Statistik

\section{Variabel Kepemilikan Mobil}

$\mathrm{T}_{\text {hitung }}=22.383$ (lihat Tabel 4.13)

$\mathrm{T}_{\text {Tabel }}=1,96 \quad$ (lihat Tabel- $\mathrm{T}$

Statistik)

Sig. $=0,000$ (lihat Tabel 4.13)

\section{Variabel Anggaran transportasi}

\section{tiap bulan (Juta)}

$\mathrm{T}_{\text {hitung }}=5.337$ (lihat Tabel 4.12)

$\mathrm{T}_{\text {Tabel }}=1,96 \quad$ (lihat Tabel- $\mathrm{T}$

Statistik)
Sig. $=0,000$ (lihat Tabel 4.12)

Keputusan Uji

Karena nilai $\mathrm{T}_{\text {hitung }}>\mathrm{T}_{\text {Tabel }}$ dan Sig. $\leq \alpha$ maka : TOLAK $\mathrm{H}_{0}$

\section{Kesimpulan}

Dengan tingkat signifikansi $5 \%$, maka secara parsial Kepemilikan Mobil, Anggaran transportasi tiap bulan (Juta) berpengaruh terhadap variabel terikat (Perjalanan Total Keluarga dengan Mobil).

\section{Uji statitisk F / Uji Simultan / Anova}

Uji keterandalan model atau uji kelayakan model atau yang lebih populer disebut sebagai uji F (ada juga yang menyebutnya sebagai uji simultan model) merupakan tahapan awal mengidentifikasi model regresi yang diestimasi layak atau tidak. Layak (andal) disini maksudnya adalah model yang diestimasi layak digunakan untuk menjelaskan pengaruh variabel-variabel bebas terhadap variabel terikat. Nama uji ini disebut sebagai uji F, karena mengikuti mengikuti distribusi $\mathrm{F}$ yang kriteria pengujiannya seperti One Way Anova.

Pengunaan software SPSS memudahkan penarikan kesimpulan dalam uji ini. Apabila nilai prob. F hitung (ouput SPSS ditunjukkan pada kolom sig.) lebih kecil dari tingkat kesalahan/error 
(alpha) 0,05 (yang telah ditentukan) maka dapat dikatakan bahwa model regresi yang diestimasi layak, sedangkan apabila nilai prob. F hitung lebih besar dari tingkat kesalahan 0,05 maka dapat dikatakan bahwa model regresi yang diestimasi tidak layak.

Tabel 4.13 Annova Model- $\mathrm{Y}_{\mathrm{A1}}$

\begin{tabular}{|r|r|r|r|r|c|c|}
\hline \multicolumn{2}{|l|}{ Model } & $\begin{array}{c}\text { Sum of } \\
\text { Squares }\end{array}$ & df & $\begin{array}{c}\text { Mean } \\
\text { Square }\end{array}$ & F & Sig. \\
\hline \multirow{3}{*}{ YA1 } & Regression & 11822.93 & 2 & 5911.465 & 477.553 & $.000^{b}$ \\
\cline { 2 - 7 } & Residual & 8380.358 & 677 & 12.379 & & \\
\cline { 2 - 7 } & Total & 20203.288 & 679 & & & \\
\hline
\end{tabular}

a. Dependent Variable:

Perjalanantotalkeluargadenganmobild lmlminggu

b. Predictors: (Constant), Anggaran transportasi tiap bulan (Juta), Mobil

Sumber : Analisis Data

Hipotesis

$\mathrm{H}_{0}=$ (Pengaruh variabel $\mathrm{Xi}$ secara bersama-sama terhadap variabel $\mathrm{Y}_{1 \mathrm{~A}}$ tidak signifikan/tidak sesuai)

$\mathrm{H}_{1}=$ (Pengaruh variabel $\mathrm{Xi}$ secara bersama-sama terhadap variabel $\mathrm{Y}_{1 \mathrm{~A}}$ signifikan/ sesuai)

- Tingkat signifikansi $\alpha=0,05$ atau 5\%

- Daerah kritis Fhitung > FTabel ; Tolak H0

- Sig. $\leq \alpha$; Tolak H0

- Uji-F Statistik

Fhitung $=477,553($ lihat Tabel 4.13)

FTabel $=2,618$ (lihat Tabel FStatistik)

Sig. $=0,000$ (lihat Tabel 4.13)

- Keputusan Uji
Karena nilai $\mathrm{F}_{\text {hitung }}>\mathrm{F}_{\text {Tabel }}$ dan Sig. $\leq \alpha$ maka : TOLAK $\mathrm{H}_{0}$

- Kesimpulan

Dengan tingkat signifikansi 5\%, variabel bebas (predictors) yaitu Kepemilikan Mobil, Anggaran transportasi tiap bulan (Juta) secara bersama-sama berpengaruh terhadap variabel terikat (Perjalanan Total Keluarga dengan Mobil).

\section{Uji Asumsi Klasik}

Sebuah model regresi akan dapat dipakai untuk prediksi jika memenuhi sejumlah asumsi yang di sebut dengan "asumsi klasik".

\section{Uji Multikoreliniaritas}

Dari hasil pengolahan data dengan SPSS seperti Tabel 4.13 di atas maka dilakukan Uji Multikoreliniaritas. Dilihat dari nilai VIF pada kepemilikan mobil , anggaran transportasi bernilai 1,443 . Karena nilai VIF dari ketiga variabel tidak ada yang lebih besar dari 10 maka dapat dikatakan tidak terjadi multikolinieritas pada ketiga variabel bebas tersebut. Dan nilai tolerance $0.693>0,1$ yang berarti tidak terjadi gejala multikorelliniaritas, sehingga model tersebut layak digunakan dalam permodelan. 
Uji Heterokedastisidas

Pengujian heteroskedastisitas dilakukan dengan membuat Scatterplot (alur sebaran) antara residual dan nilai prediksi dari variabel terikat yang telah distandarisasi. Hasil uji heteroskedastisitas dapat dilihat pada gambar Scatterplot, seperti pada gambar 4.1.

Dari gambar 4.1 terlihat bahwa sebaran titik tidak membentuk suatu pola/alur tertentu, sehingga dapat disimpulkan tidak terjadi heteroskedastisitas atau dengan kata lain terjadi homoskedastisitas. Asumsi klasik tentang heteroskedastisitas dalam model ini terpenuhi, yaitu terbebas dari heteroskedastisitas.

\section{Uji Normalitas}

Hasil uji normalitas dapat dilihat dari Gambar 4.2. Normal P-P Plot. Perlu diingatkan bahwa asumsi normalitas yang dimaksud dalam asumsi klasik pendekatan OLS adalah (data) residual yang dibentuk model regresi linier terdistribusi normal, bukan variabel bebas ataupun variabel terikatnya. Kriteria sebuah (data) residual terdistribusi normal atau tidak dengan pendekatan Normal P-P Plot dapat dilakukan dengan melihat sebaran titiktitik yang ada pada gambar. Apabila sebaran titik-titik tersebut mendekati atau rapat pada garis lurus (diagonal) maka dikatakan bahwa (data) residual terdistribusi normal, namun apabila sebaran titik-titik tersebut menjauhi garis maka tidak terdistribusi normal.

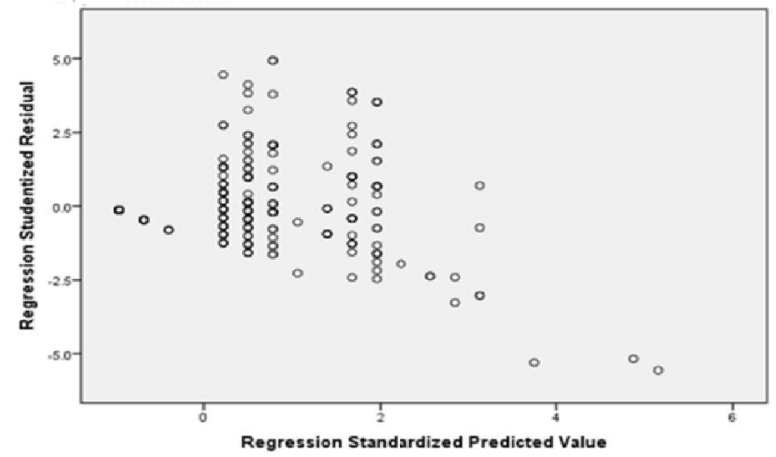

Gambar 4.1 Scatterplot Model- $\mathrm{Y}_{\mathrm{A} 1}$

Sebaran titik-titik dari gambar Normal P-P Plot di atas relatif mendekati garis lurus, sehingga dapat disimpulkan bahwa (data) residual terdistribusi normal.

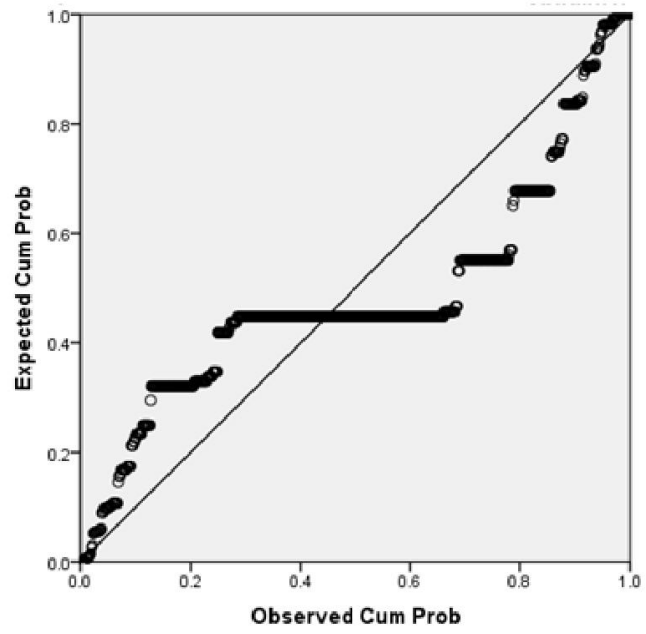

Gambar 4.2 Normal P-P Plot Model- $\mathrm{Y}_{\mathrm{A} 1}$

Setelah lolos melewati semua uji maka di dapatkanlah Model Jumlah Perjalanan Keluar Perumahan Dengan Menggunakan Mobil Dalam Satu Minggu adalah : 
YA1 $=0,465+4,915 X_{3}+1,172 X_{6}$

dengan $R^{2}=0,585$

Dengan YA1 = Jumlah perjalanan keluar perumahan dengan menggunakan mobil

X3 = Jumlah kepemilikan mobil

$\mathrm{X} 6=$ Jumlah anggaran transportasi

Dengan cara yang sama di dapatkan pemodelan bangkitan perjalanan dengan :

- Bangkitan perjalanan dengan sepeda motor :

$$
Y_{\mathrm{A} 2}=-0,407+1,324 X_{2}+5,466 X_{4}
$$

dengan $R^{2}=0,445$

Dengan $\quad \mathrm{Y}_{\mathrm{A} 2}=$ Jumlah perjalanan keluar perumahan dengan menggunakan sepeda motor

$\mathrm{X}_{2}=$ Jumlah Anggota Keluarga

$\mathrm{X}_{4}=$ Jumlah Kepemilikan Sepeda

Motor

Bangkitan perjalanan dengan

gabungan sepeda motor dan mobil :

$\mathrm{YA3}=2,271+1,324 \times 2+4,344 \times 5+1,228 \times 6$

dengan $R 2=0,404$

Dengan : YA3 = Jumlah perjalanan keluar perumahan dengan menggunakan mobil dan sepeda motor

X2 = Jumlah Anggota Keluarga

X5 = Jumlah Kepemilikan Mobil dan Sepeda Motor

X6 = Anggaran transportasi tiap bulan (Juta)

\section{Pemodelan Bangkitan Perjalanan}

\section{Berdasarkan Tipe Rumah}

Dengan cara yang sama di dapatkan model bangkitan perjalanan yang di bedakan berdasarkan tipe rumah. Pemodelan yang di dapatkan dapat di lihat pada Tabel 4.14.

\section{Validasi Model}

Validasi merupakan langkah yang penting dalam pemodelan. Tujuan dari validasi model adalah untuk mengukur sejauh mana hasil model mendekati kondisi sebenarnya. Semakin dekat hasil model dengan data lapangan, semakin valid model tersebut dalam menggambarkan kondisi lapangannya.

Tabel 4.14 Pemodelan Bangkitan Perjalanan berdasar Type Rumah

Pemodelan Bangkitan Perjalanan Berdasarkan Type Rumah

\begin{tabular}{|c|c|c|}
\hline Jenis Perjalanan & \multicolumn{2}{|l|}{ Type Rumah Type 45} \\
\hline Dengan sepeda motor & $Y=-0,313+6,311 X_{3}+1,06 X_{6}$ & $\mathrm{R}^{2}=0,706$ \\
\hline Dengan mobil & $Y=-0,521+1,226 \mathrm{X} 2+5,071 \mathrm{X} 4$ & $R^{2}=0,481$ \\
\hline \multirow[t]{2}{*}{ Gabungan motor dan mobil } & $\mathrm{Y}=0,886+1,572 \mathrm{X} 2+3,836 \mathrm{X} 5+1,792 \times 6$ & $R^{2}=0,453$ \\
\hline & \multicolumn{2}{|l|}{ Type Rumah Type 70} \\
\hline Dengan sepeda motor & $Y=-1,240+1,813 \mathrm{X} 2+5,147 \mathrm{X} 4$ & $\mathrm{R}^{2}=0,396$ \\
\hline Dengan mobil & $Y=0,777+3,546 X_{3}+1,173 X_{6}$ & $R^{2}=0,512$ \\
\hline \multirow[t]{2}{*}{ Gabungan motor dan mobil } & $Y=2,477+1,614 X 2+4,119 X 5$ & $R^{2}=0,339$ \\
\hline & \multicolumn{2}{|l|}{ Type Rumah Type 100} \\
\hline Dengan sepeda motor & $Y=-0,857+1,382 X 2+5,039 X 4$ & $\mathrm{R}^{2}=0,474$ \\
\hline Dengan mobil & $Y=6,448+5,199 X 3-0,288 \mathrm{X} 8$ & $R^{2}=0,586$ \\
\hline Gabungan motor dan mobil & $\mathrm{Y}=2,972+1,132 \times 2+4,570 \mathrm{X5}$ & $\mathrm{R}^{2}=0,364$ \\
\hline
\end{tabular}

$\mathrm{X} 1=$ Jumlah Penghasilan Total Keluarga

X2 = Jumlah Anggota Keluarga

X3 = Jumlah Kepemilikan Mobil

X4 = Jumlah Kepemilikan Sepeda Motor

X5 = Jumlah Kepemilikan Mobil dan Sepeda Motor

X6 = Anggaran transportasi tiap bulan (Juta)

$\mathrm{X} 8=$ Umur Perumahan

Sumber : Analisis Data

\section{Validasi model umumnya dilakukan} dengan menggunakan metode perbandingan secara statistik. Salah satu metode statistik yang dapat digunakan 
untuk memvalidasi model adalah metode Chi-Square. Metode ini mampu memberikan batasan yang jelas apakah performa model yang kita gunakan valid atau tidak.

Rumus Chi Square :

$$
\begin{aligned}
& x^{2}= \\
& \sum_{i=1}^{n} \frac{\left(\text { observed value }_{i} \text {-expected } \text { value }_{i}\right)^{2}}{\text { expected value }_{i}}
\end{aligned}
$$

Observed Value $=$ Data hasil Survey

Expected Value $=$ Data hasil model

Syarat sebuah model valid atau tidak adalah nilai Chi-Square hitung harus lebih kecil dari Chi square tabel.

Perhitungan validasi model dengan menggunkan Metode Chi Square untuk model-model yang telah di dapakan sebelumnya dapat di lihat pada Lampiran III pada tesis ini. Hasil bangkitan perjalanan yang di dapatkan dengan pemodelan di bandingkan dengan hasil perjalananan menggunakan data lapangan yang di dapatkan dari hasil survey yang sampelnya telah di pisahkan sebelumnya.

Rangkuman hasil perhitungan validasi masing-masing model dengan Metode Chi Square dapat di lihat pada Tabel 4.15

Dari Tabel 4.15 dapat di lihat bahwa masing-masing model bangkitan perjalanan telah memenuhi syarat uji validasi. Dan hasilnya semua model dapat di terima. Yang berarti model yang di dapatkan dapat memberi gambaran bangkitan perjalanan dari zona perumahan. Data dari hasil model tidak jauh berbeda dengan data hasil survey di lapangan.

Tabel 4.15 Hasil Uji Validasi Model

\begin{tabular}{|c|c|c|c|}
\hline \multirow{2}{*}{ Model } & \multicolumn{3}{|c|}{ Chi-Square Test $\mathbf{d g} \boldsymbol{\alpha}=\mathbf{0 , 0 5}$} \\
\cline { 2 - 4 } & $\gamma$ & $\gamma \mathbf{0}$ & Terima/tolak \\
\hline $\mathrm{Y}_{\mathrm{A} 1}=0,465+4,915 \mathrm{X}_{3}+1,172 \mathrm{X}_{6}$ & 17.12 & 18.37 & Terima \\
\hline $\mathrm{Y}_{\mathrm{A} 2}=-0,407+1,324 \mathrm{X}_{2}+5,466 \mathrm{X}_{4}$ & 5 & 18.37 & Terima \\
\hline $\mathrm{Y}_{\mathrm{A} 3}=2,271+1,324 \mathrm{X}_{2}+4,344 \mathrm{X}_{5}+1,228 \mathrm{X}_{6}$ & 16.37 & 18.37 & Terima \\
\hline $\mathrm{Y}_{45 \mathrm{~A}}=-0,313+6,311 \mathrm{X}_{3}+1,06 \mathrm{X}_{6}$ & 3.92 & 18.37 & Terima \\
\hline $\mathrm{Y}_{45 \mathrm{~B}}=-0,521+1,266 \mathrm{X}_{2}+.5,071 \mathrm{X}_{4}$ & 16.26 & 18.37 & Terima \\
\hline $\mathrm{Y}_{45 \mathrm{C}}=0,886+1,572 \mathrm{X}_{2}+3,836 \mathrm{X}_{5}+1,792 \mathrm{X}_{6}$ & 6.16 & 18.37 & Terima \\
\hline $\mathrm{Y}_{70 \mathrm{~A}}=0,777+3,546 \mathrm{X}_{3}+1,173 \mathrm{X}_{6}$ & 8.91 & 18.37 & Terima \\
\hline $\mathrm{Y}_{70 \mathrm{~B}}=-1,240+1,813 \mathrm{X}_{2}+5,147 \mathrm{X}_{4}$ & 13.87 & 18.37 & Terima \\
\hline $\mathrm{Y}_{70 \mathrm{C}}=2,477+1,614 \mathrm{X}_{2}+4,119 \mathrm{X}_{5}$ & 14.14 & 18.37 & Terima \\
\hline $\mathrm{Y}_{100 \mathrm{~A}}=6,448+5,199 \mathrm{X}_{3}-0,288 \mathrm{X}_{8}$ & 57.5 & 18.37 & Terima \\
\hline $\mathrm{Y}_{100 \mathrm{~B}}=-0,857+1,382 \mathrm{X}_{2}+5,039 \mathrm{X}_{4}$ & 16.09 & 18.37 & Terima \\
\hline $\mathrm{Y}_{100 \mathrm{C}}=2,972+1,132 \mathrm{X}_{2}+4,570 \mathrm{X}_{5}$ & 17.76 & 18.37 & Terima \\
\hline
\end{tabular}

Sumber : Analisis Data

\section{Analisis Tipe Rumah Terhadap \\ Bangkitan Perjalanan}

Dalam Tabel 4.7 terlihat bahwa rata-rata bangkitan perjalanan dengan mobil sejalan dengan kenaikan tipe rumah. Namun pada rumah Tipe Rumah 36 rata-rata perjalanannya cukup tinggi dibandingkan dengan Tipe Rumah 45 dan tipe di atasnya. Untuk keperluan analisis, peneliti mencoba melihat kembali data perjalanan yang dilakukan oleh rumah Tipe 36 tersebut. Dengan cara mendeteksi nilai-nilai outlier. Maka untuk keperluan analisis data-data yang tidak biasa ini di 
keluarkan. Dan perubahan data tersebut dapat di lihat pada Tabel 4.16.

Pada dasarnya data-data outlier harus di keluarkan terlebih dahulu. Data outliers maksudnya adalah suatu data yang jauh berbeda dibandingkan terhadap keseluruhan data.

Deteksi data dengan standarisasi pada prinsipnya mengubah nilai data menjadi bentuk $\mathrm{z}$, yaitu dengan rumus berikut 4.5.

$$
Z=\frac{x_{i}-\bar{x}}{s}
$$

$$
\text { Dimana } \begin{aligned}
x_{i} & =\text { nilai pengamatan ke- } \mathrm{i} \\
\bar{x} & =\text { rata-rata nilai pengamatan } \\
\mathrm{S} & =\text { standar deviasi nilai } \\
& \text { pengamatan }
\end{aligned}
$$

Data dikatakan outlier atau terpencil (pencilan) apabila nilai Z lebih besar dari $+2,5$ atau $Z$ lebih kecil dari -2,5 Dari hasil pengolahan data dengan SPSS di keluarkan data-data sampel yang memiliki $Z$ besar dari $\pm 2,5$.

Dari data sampel yang ada di lakukan proses deteksi data outlier menggunakan program SPSS dengan indikator nilai Z. Data yang yang memiliki nilai $\mathrm{Z}$ lebih dari $\pm 2,5$ dikeluarkan. Dan hasilnya dapat dilihat pada Tabel 4.16. Untuk Tipe Rumah 36 yang awalnya mempunyai rata-rata 6,76 berubah menjadi 4,4. Terlihat bahwa ada beberapa data pada Tipe 36 yang jumlah bangkitan perjalanan dengan mobil mempunyai beberapa data outlier yang harus di keluarkan. Begitu juga ada beberapa sampel pada tipe lain yang juga memiliki data outlier.

Dari data yang ada pada Tabel 4.16 kemudian dilakukan proses regresi untuk masing-masing jenis perjalanan.

Tabel 4.16 Tipe Rumah dan Bangkitan Perjalanan dengan mobil

\begin{tabular}{|c|c|c|r|}
\hline $\begin{array}{c}\text { Tipe } \\
\text { Rumah }\end{array}$ & $\begin{array}{c}\text { Jumlah } \\
\text { Rumah }\end{array}$ & $\begin{array}{c}\text { Perjalanan Total } \\
\text { Keluarga dengan } \\
\text { mobil (awal) }\end{array}$ & $\begin{array}{c}\text { Perjalanan Total Keluarga } \\
\text { dengan mobil (setelah data } \\
\text { outlier dikeluarkan) }\end{array}$ \\
\hline 21 & 13 & 0.31 & 0.31 \\
\hline 36 & 46 & 6.76 & 3.4 \\
\hline 45 & 174 & 3.75 & 2.38 \\
\hline 54 & 15 & 2.73 & 4.2 \\
\hline 60 & 35 & 4.2 & 3.56 \\
\hline 70 & 215 & 3.8 & 5.48 \\
\hline 80 & 31 & 5.48 & 5.07 \\
\hline 100 & 108 & 5.58 & \\
\hline 110 & 17 & 5.94 & - \\
\hline 120 & 23 & 7.04 & \\
\hline 130 & 2 & 10 & \\
\hline 140 & 1 & 10 & \\
\hline Total & $\mathbf{6 8 0}$ & & \\
\hline
\end{tabular}

Sumber : Analisis Data

Hasil proses regresi dapat dilihat pada Gambar 4.3. Dari regresi tersebut terlihat bahwa tipe rumah berkorelasi cukup kuat dengan jumlah bangkitan perjalanan dengan mobil. Dengan nilai $\mathrm{R}^{2}$ $=0,5838$. 


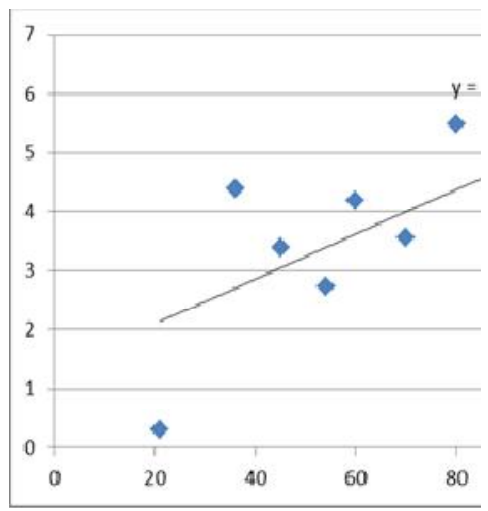

Gambar 4.3 Grafik regresi Linier Tipe Rumah dan Jumlah Bangkitan Perjalanan dengan Mobil

Dari grafik pada Gambar 4.3 di atas di dapatkan persamaan

$$
\mathrm{Y}=\mathbf{0 , 0 3 7 9} \mathrm{X}+\mathbf{1 , 3 4 7 3}
$$

Dengan nilai $R^{2}=\mathbf{0 , 5 8 3 8}$.

Dimana

$\mathrm{Y}=$ Jumlah Bangkitan Perjalanan dengan

Mobil

$\mathrm{X}=$ Tipe Rumah (Berdasarkan luas rumah)

Hasil regresi linier untuk tipe rumah dan Bangkitan perjalanan dengan sepeda motor dapat di lihat pada gambar 4.4 .

Terlihat dari Gambar 4.4 bahwa Tipe Rumah dan bangkitan perjalanan dengan sepeda motor tidak memiliki korelasi yang kuat dengan nilai $\mathrm{R}^{2}=0.0949$ yang sangat rendah.

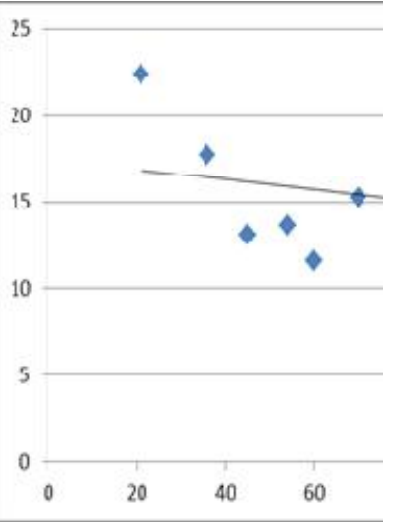

Gambar 4.4 Grafik regresi Linier Tipe Rumah dan Jumlah Bangkitan Perjalanan dengan Sepeda

Motor

\section{PENUTUP}

\section{Kesimpulan}

Berdasarkan pada hasil pengolahan data dan analisis terhadap bangkitan perjalanan penghuni perumahan, maka dapat diambil kesimpulan :

1. Berdasarkan hasil survei terhadap 680 rumah sebagai sampel pada penelitian ini dapat diketahui karakteristik rumah tangga sebagai berikut :

a. Penghuni perumahan umumnya beranggotakan 4-5 orang per rumah tangga yaitu sebesar $32.65 \%$ dan $27.21 \%$.

b. Kepemilikan sepeda motor umumnya 2 unit per rumah $42.79 \%$ dan hampir separuh dari responden memiliki mobil 1 unit per rumah (42.21\%).

2. Karakteristik perjalanan/pergerakan penghuni rumah yang ditinjau adalah

a. Pergerakan total rata-rata penghuni rumah dengan menggunakan sepeda 
motor keluar perumahan dalam satu minggu adalah 14.36 atau 2.05 kali perhari dengan mobil sebanyak 4,47 kali dalam seminggu atau 0,64 kali dalam sehari.

b. Variabel yang paling mempengaruhi jumlah perjalanan dengan motor adalah Jumlah anggota keluarga dan jumlah kepemilikan sepeda motor.

c. Variabel yang paling berpengaruh dalam bangkitan perjalanan dengan mobil adalah jumlah kepemilikan mobil dan jumlah anggaran yang disediakan untuk transportasi.

3. Variabel umur perumahan berkorelasi sangat rendah dengan jumlah pergerakan penduduk yaitu kurang dari 0,2 yang berarti tidak menunjukkan korelasi. Variabel type perumahan berkorelasi cukup tinggi dengan bangkitan perjalan dengan mobil nilai $R^{2}=0,583$. Namun berkebalikan dengan motor yang hanya memiliki $\mathrm{R}^{2}=0,0949$.

\section{Saran}

1. Hampir separuh rumah memiliki mobil maka penting bagi developer perumahan untuk mempertimbangkan penyediaan sarana jalan yang memadai di lingkungan perumahan yang mengakomodasi pengembangan 20 tahun yang akan datang.
2. Besarnya pergerakan perjalanan dari perumahan maka perlu dilakukan andalalin sebelum pemerintah memberikan izin pembangunan perumahan.

3. Untuk kepentingan penelitian, perlu dikembangkan variabel-variabel lain yang berpengaruh seperti aksesibilitas, karakteristik tata guna lahan, faktor sosial ekonomi lainnya.

\section{DAFTAR PUSTAKA}

Algifari. (2000). "Analisis Regresi, Teori, Kasus \& Solusi”. BPFE UGM. Yogyakarta.

Bella, Rosmiyati., et. Al.(2013). "Pemodelan Bangkitan Perjalanan Berbasis Rumah Tangga di Kompleks RSS. Baumata, Kecamatan Taebenu, Kabupaten Kupang". Jurnal Teknik Sipil, Vol. II. No. 1, April 2013.

BPS Kota Padang, (2014). Padang Dalam Angka 2014. BPS Kota Padang

Ersandi, et al.(2009). "Model Bangkitan Perjalanan Kerja dan Faktor Aksesibilitas pada Zona Perumahan di Yogyakarta". Semesta Teknika, Vol.12, No.1, 44-54, Mei 2009.

Hermanto, Edy. (2009). "Bangkitan Pergerakan Perjalanan ke Tempat Kerja Studi Kasus Perumahan Johor Indah Permai I Medan". Tesis. Universitas Sumatera Utara Medan.

Morlok, E. K. (1991). "Pengantar Teknik dan Perencanaan Transportasi". Penerbit Erlangga,Jakarta.

Santoso, E. (2001). “Tinjauan aksesibilitas transportasi lingkungan perumahan 
(studi kasus di Semarang)". Tesis Magister Sistem dan Teknik Transportasi, Universitas Gadjah Mada, Yogyakarta.

Santoso, Singgih (2000). Buku Latihan SPSS Statistik Parametrik. Jakarta: PT Elex Media Komputindo.

Sarwono, J. (2006). "Metode Penelitian Kuantitatif dan Kualitatif", Graha Ilmu, Yogyakarta.

Sugiyono, (2011)."Metode Penelitian Kuantitaif Kualitatif dan R\&D". Cetakan Ke-13, Alfabeta, Bandung.

Supriyono. (2012). “Analisis Pengaruh Bangkitan Perjalanan Penduduk Terhadap Kinerja Jalan Utama Kawasan Perumahan Bukit Banaran Semarang". Universitas Diponegoro. Semarang.
Unknown,(2007). "Pedoman Analisis Dampak Lalu Lintas Jalan Akibat Pengembangan Kawasan di Perkotaan", Departemen PU.

Tamin, O.Z. (2000). "Perencanaan dan Pemodelan

Transportasi".Bandung. Edisi Kedua. Institut Teknologi Bandung Press.

Warpani, S. (1981). "Perencanaan Transport".Institut Teknologi Bandung. Bandung.

Warpani, S, (1990). "Merencanakan Sistem Pengangkutan", Bandung: Institut Teknologi Bandung Press.

Widarjono, Agus (2005), Ekonometrika: Teori dan Aplikasi, Yogyakarta: Ekonisia 
